iation of the rigours of the scientific method.

Mr Cornell is at his most dogmatic in the chapter on Stonehenge, which is disappointing and, indeed, infuriating. Here we see regurgitated the Stonehenge debate of the 1960s, with Gerald Hawkins hailed as "having refuted nearly a century of archaeological dogma" and "having begun a revolution that would lead to a complete rethinking of the intellectual development of humankind", while archaeologists such as Richard Atkinson are denigrated for daring to criticize, and are said to be motivated by their "traditional view of these people as backward barbarians"'. In the same chapter Lockyer's earlier theories are discussed and justly criticized, but when it comes to Hawkins there is suddenly a flagrant disregard for any objective discussion. Instead, as one encounters more and more references throughout the book to Hawkins's "pioneering research at Stonehenge", how he has been praised as the "father of archaeoastronomy", and how he "almost single-handedly changed public and scientific conceptions of archaeoastronomy", one begins to wonder if this isn't really a Gerald Hawkins tribute volume.

It is certainly true that Hawkins's work on Stonehenge led to a general public interest in archaeoastronomy and it is undeniable that Hawkins has done much work of value in this field, but the work on Stonehenge itself was soon criticized on justifiable grounds. It is perhaps worth (tiresome though it is to have to do so, for it has been done several times) briefly putting the record straight here. The astronomical interpretation of Stonehenge I rests on the finding that 24 out of 50 possible alignments between pairs of features at Stonehenge I were of astronomical significance. The chances of this happening fortuitously were calculated by Hawkins to be less than one in a million, as quoted by Cornell. In fact, there were 24 lines out of a total possible of over 100 , since alignments both ways along most pairs were allowed as possibly astronomical; Hawkins calculated the probability of exactly 24 astronomical "hits" rather than 24 or more, and different tolerances were allowed on different lines. When these errors are taken into account, no evidence whatsoever remains for preferential astronomical orientation. This is quite apart from any archaeological and other arguments about the choice of features for inclusion in the analysis. These errors are simple ones certainly not a case for "mathematicians still arguing" as stated by Cornell - and, although they were pointed out by Atkinson only a year after the publication of Hawkins's Stonehenge Decoded (Doubleday, 1965), even now they are still present in current reprints of the book. This fact does not imply any great commitment to objective research, and it is tragic that Cornell's book, if widely read, will only revitalize public misconceptions on this point. Cornell rightly points out that Hawkins's conclusions "never seemed to bother a technically attuned public": with the exception, one may surmise, of those with a questioning mind and some high-school mathematics.

In the chapter on Stonehenge and British archaeoastronomy in general, the author dismisses the archaeoastronomical work of Professor Alexander Thom in less than three pages, and mentions later that Thom's work scores a very low "reliability value" according to criteria devised by Hawkins (under which, not surprisingly, Hawkins's own work scores a high value). This sort of denigration is insidious. Thom has investigated a large number of sites, presented his results in a manner so that they can be readily re-examined and criticized and has been prepared to modify his opinions in the light of criticism and new evidence. (I am amongst those attempting critical assessments of his work.) In this manner, hypotheses are presented, criticized and modified, a procedure in accord with the scientific method but perhaps less susceptible to large-scale popular interest.

There are a number of minor errors in the book which there is no room to mention in detail, particularly amongst the astronomical background material cunningly concealed amidst discussion of Toro Muerto and Marshack's work (that it is cunningly concealed is not a criticism).

But the overriding criticism of this book must be its one-sided and misleading treatment of British archaeoastronomy, in particular the almost fanatical praise of Hawkins and detriment of his critics. The complete break with objectivity in this respect must invalidate the value of the rest of the book, at least for non-specialist readers (and this is the intended audience) who cannot judge for themselves. Indeed, it will quite possibly have a worse effect, for in raking up past confusions and prejudices, amongst an objective discussion of other fields of archaeoastronomy, together with its several references to the prejudice of archaeologists against new ideas, it threatens to direct popular support towards sensationalism and away from level-headed scientific research.

Clive Ruggles is University of Wales Research Fellow in the Department of Archaeology at University College, Cardiff.

\title{
Exploring Britain's prehistoric past
}

\section{Ruth D. Whitehouse}

The Penguin Guide to Prehistoric England and Wales. By James Dyer. Pp. 384. ISBN 0-7139-1149-6. (Allen Lane: 1981.) £9.50.

POPULAR interest in archaeology in the British Isles has never been higher, an interest which has brought increasing numbers of visitors to the visible remains of our past, our ancient monuments. James Dyer's book is a concise guide to almost a thousand of the most interesting sites of the prehistoric period in England and Wales. It is not the only guide of its kind: competitors include Nicholas Thomas's Guide to Prehistoric England (Batsford, 2nd Edn 1973), Richard Wainwright's $A$ Guide to the Prehistoric Remains in Britain: South and East (Constable, 1978) and James Dyer's own Southern England: An Archaeological Guide (Faber, 1973).

The advantage of the new Penguin guide over these other works is its wider geographical coverage and the larger number of sites included. It begins with a section of five maps and a short introduction to British prehistory. The main part of the book consists of a gazetteer of sites, listed alphabetically by county. The gazetteer itself is excellent: the accounts of sites are concise and accurate, with Ordnance Survey grid references included; many of the site descriptions include one or more bibliographical references and some are illustrated with photographs or line drawings. The visitor is therefore provided both with clear descriptions and an introduction to further reading.

Less satisfactory is the introduction. Archaeology today is developing fast and is characterized by controversy and debate on almost every topic. Dyer ignores this and presents a consensus view of British prehistory, which may accurately reflect majority opinion, but which neglects the new approaches and hypotheses that have transformed the subject in recent years. To take a single example, the Beaker pottery and associated artefacts of the third millennium $\mathrm{BC}$ are explained in terms of people migrating into and across England. This is indeed the traditional interpretation, but there is an alternative view that they represent a "status kit" of prestigious objects which were acquired by influential and wealthy people in different societies and were distributed not by migration, but by trade or exchange. While a guide book is not perhaps the proper forum for the airing of controversy, the onus surely remains to provide an up-to-date level of interpretation. Nonetheless, this is a book that everyone interested in Britain's prehistoric past will wish to own.

Ruth D. Whitehouse is a Lecturer in Prehistoric Archaeology at the University of Lancaster. 